\title{
Pengaruh Pemberian Pupuk Feses Sapi dengan Dosis yang Berbeda Terhadap Pertumbuhan dan Produksi Rumput Odot (Pennisetum purpureum $C v$. Mott) di Kabupaten Kepahiang
}

\section{The Influence of Giving Cow Fertilizer Fertilizers with Different Doses on the Growth and Production of Odot Grass (Pennisetum purpureum Cv. Mott) in Kepahiang District}

\author{
W. A. Sulaiman, Dwatmadji, dan T. Suteky \\ Jurusan Peternakan, Fakultas Pertanian Universitas Bengkulu \\ Jl. WR. Supratman, Kandang Limun, Bengkulu \\ Corresponding e-mail : wisnu.sulaiman1922@gmail.com
}

\begin{abstract}
This study aimed to determine the growth and production of Odot grass (Pennisetum purpureum Cv.Mott) by giving different doses. The study was conducted in Tugu Rejo Village, Kec. Kabawetan, Kab. Kepahiang, Prov. Bengkulu using Randomized Block Design (RBD), with 4 treatments P0 (Control), P1 (cow feces fertilizer 10 tons / ha), P2 (cow feces fertilizer 15 tons / ha) and P3 (cow feces fertilizer 20 tons / ha) each treatment consisted of 6 replications and $2 \mathrm{~cm}$ thick coffee skin mulch. The variables observed included growth and production of Odot grass. The data obtained was analyzed by using variance (ANOVA), if it had a significant effect it would be carried out further testing of Duncan's Multiple Range Test (DMRT). The results showed the treatment had no significant effect $(\mathrm{P}>0.05)$ on plant height and leaf length but had a significant effect $(\mathrm{P}<0.05)$ on leaf width and had a very significant effect $(\mathrm{P}<0.01)$ on the number of tillers and material production dried Odot grass (Pennisetum purpureum Cv.Mott). The conclusions of this study were using 15 tons / ha cow feces fertilizer +2 $\mathrm{cm}$ coffee skin mulch better for growth and Odot grass production (Pennisetum purpureum Cv.Mott).
\end{abstract}

Key words: Cow faecal fertilizer, growth, production, Pennisetum purpureum Cv.Mott

\begin{abstract}
ABSTRAK
Penelitian ini bertujuan mengetahui pertumbuhan dan produksi rumput Odot (Pennisetum purpureum Cv. Mott) dengan pemberian dosis yang berbeda. Penelitian dilakukan di Desa Tugu Rejo, Kec. Kabawetan, Kab. Kepahiang, Prov. Bengkulu dengan menggunakan Rancangan Acak Kelompok (RAK), dengan 4 perlakuan P0 (Kontrol), P1(pupuk feses sapi 10 ton/ha), P2 (pupuk feses sapi 15 ton/ha) dan P3 (pupuk feses sapi 20 ton/ha) setiap perlakuan terdiri dari 6 ulangan dan mulsa kulit kopi setebal $2 \mathrm{~cm}$. Variabel yang diamati meliputi pertumbuhan dan produksi rumput Odot. Data yang diperoleh di analisa dengan menggunakan sidik ragam (Anova), bila berpengaruh nyata maka akan dilakukan uji lanjut Duncan's Multiple Range Test (DMRT). Hasil penelitian menunjukan perlakuan tidak berpengaruh nyata $(\mathrm{P}>0,05)$ terhadap tinggi tanaman dan panjang daun namun berpengaruh nyata $(\mathrm{P}<0,05)$ terhadap lebar daun dan berpengaruh sangat nyata $(\mathrm{P}<0,01)$ terhadap jumlah anakan serta produksi bahan kering rumput Odot (Pennisetum purpureum Cv.Mott). Kesimpulan penelitian ini dengan menggunakan dosis pupuk feses sapi 15 ton/ha + mulsa kulit kopi setebal $2 \mathrm{~cm}$ lebih baik terhadap pertumbuhan dan produksi rumput Odot (Pennisetum purpureum Cv. Mott).
\end{abstract}

Kata kunci : Pupuk feses sapi, pertumbuhan, produksi, Pennisetum purpureum Cv. Mott

\section{PENDAHULUAN}

Ketersediaan akan hijauan pada saat ini semakin terbatas. Pakan hijauan merupakan pakan pokok pada ruminansia (Rukmana, 2005). Salah satu rumput budidaya yang dapat dikembangkan yaitu rumput Odot (Pennisetum purpureum Cv.Mott). Rumput Odot (Pennisetum purpureum $C v$. Mott) atau biasa dinamakan dwarf elephant grass merupakan jenis rumput unggul yang memiliki produktivitas yang tinggi dan kandungan nutrisi yang cukup baik. Kultivar ini memiliki karakteristik perbandingan rasio daun yang tinggi dibandingkan batang (Lasamadi et al, 2013).

Penggunaan pupuk anorganik secara terus menerus tanpa aturan juga dapat mengganggu keseimbangan sifat tanah, 
menurunkan produktifitas lahan, dan dapat mempengaruhi produksi tanaman. Perlu adanya upaya peningkatan penggunaan pupuk yang dikaitkan dengan aspek pendukung kelestarian alam, yaitu dengan penggunaan pupuk organik (AAK, 1983). Salah satu pupuk organik yang dapat dimanfaatkan adalah pupuk kandang.Penggunaan pupuk kandang sebagian besar hanya digunakan sedikit sebagai pupuk, sehingga seringkali terbuang dengan sia-sia.

Novizan (2005) melaporkan pupuk kandang sapi padat yang telah kering termasuk kedalam pupuk yang berdekomposisi lambat sehingga panas yang dikeluarkan dalam proses tersebut relatif kecil sehingga aman untuk digunakan pada tanaman pendapat ini didukung oleh Rachmawati dan Manshur (2000) pupuk kandang feses sapi paling baik untuk digunakan sebagai pupuk karena bersifat dingin. Pujisiswanto et al. (2008) melaporkan kotoran sapi memiliki kandungan nitrogen dan potasium yang baik untuk dimanfaatkan sebagai pupuk kandang. Berdasarkan penelitian Satata dan Kusuma (2014) dengan menggunakan pupuk feses sapi dengan dosis pemberian pupuk 30 ton/ha pada umur potong 8 minggu terhadap produksi rumput Brachiaria humidicola dengan rata-rata produksi berat basah mencapai $0,452 \mathrm{~kg} / \mathrm{m}^{2}$ atau 4,52 ton $/ \mathrm{ha}$. Penggunaan pupuk feses sapi juga berdasarkan penelitian Ako (1997) dengan menggunakan rumput Gajah rata-rata produksi bahan kering yaitu $186,31 \mathrm{~g} / \mathrm{m}^{2}$ dengan dosis pemupukan 10 ton/ha dengan umur potong 2 bulan dan berat segar mencapai 300 ton/ha.

Produksi rumput Odot sangat dipengaruhi pemupukan, berdasarkan hasil penelitian Dapa (2016)produksi segar rumput Odot (Pennisetum purpureum Cv. Mott) 8,29 $\mathrm{kg} / \mathrm{m}^{2}$ atau 82,9 ton $/ \mathrm{ha} / 45$ hari dengan menggunakan biourin. Penggunaan mulsa juga diharapkan dapat menghambat pertumbuhan dari tanaman liar lainnya yang dapat menghambat pertumbuhan dari rumput Odot (Pennisetum purpureum Cv. Mott).
Hillel (1980) melaporkan mulsa merupakan jenis penutup tanah buatan yang banyak digunakan untuk kegiatan budidaya tanaman, bertujuan untuk memperoleh perubahan menguntungkan pada lingkungan tanah tertentu. Purwowidodo (1983) menambahkan bahwa pemakaian mulsa atau pemulsaan untuk memperbaiki suatu lingkungan dari perakaran dan sifat-sifat tanah yang pada nantinya akan berpengaruh terhadap pertumbuhan dan produksi suatu tanaman.

Salah satu penggunaan mulsa yang digunakan adalah limbah kulit kopi. Mulia dalam Afrizon et al. (2010) melaporkan limbah kulit kopi merupakan limbah padat yang mengandung beberapa unsur makro yaitu Nitrogen, Phospor, dan Kalium.Limbah kulit kopi sebagai media mulsa banyak ditemukan di Desa Tugu Rejo, Kecamatan Kabawetan, Kabupaten Kepahiang, Provinsi Bengkulu.Sehingga penggunaan limbah kulit kopi ini sangat baik untuk dimanfaatkan. Pemotongan tanaman hijauan pakan pada umumnya dilakukan menjelang berbunga untuk menjamin pertumbuhan kembali (regrowth) yang optimal, sehat dan kandungan gizinya tinggi (Aminudin, 1990).

Kabupaten Kepahiang mempunyai ketinggian di atas 450 mdpl sampai dengan ketinggian lebih dari 900 mdpl. Dengan kelembaban dan suhu udara pada tahun 2016 yaitu kelembaban nisbi rata - rata 85,21 persen dan suhu rata - rata $24,16^{\circ} \mathrm{C}$ dengan suhu maksimum $24,9^{\circ}$ dan suhu minimum 23, $6^{0}$ C(BPS Kabupaten Kepahiang, 2017).

Dari uraian diatas mengenai penggunaan pupuk organik (feses sapi) di harapkan dapat meningkatkan produksi rumput Odot (Pennisetum purpureum $C v$.Mott) serta dengan penggunaan limbah kulit kopi sebagai penutup tanah (mulsa) dapat menguntungkan kualitas lingkungan tanah serta dapat menjadi harapan baru bagi pengembangan peternakan di Desa Tugu Rejo, Kecamatan Kabawetan, Kabupaten Kepahiang, Provinsi Bengkulu.

Penelitian ini bertujuan untuk mengevaluasi Pengaruh PemberianPupuk Feses Sapi Dengan Dosis yang Berbeda 
terhadap Pertumbuhan dan Produksi Rumput Odot (Pennisetum Purpureum Cv.Mott) di Kabupaten Kepahiang, Bengkulu. Pemberian pupuk feses sapi pada dosis yang berbeda dapat berpengaruh terhadap pertumbuhan dan produksi rumput Odot (Pennisetum purpureum $C v$. Mott).

\section{MATERI DAN METODE}

Pada metode penelitian ini antara lain yaitu meliputi waktu, bahan dan alat, serta tahapan penelitian.

Penelitian ini telah dilaksanakan pada bulan September 2017sampai bulan Januari 2018 di Desa Tugu Rejo Kecamatan Kabawetan Kabupaten Kepahiang Provinsi Bengkulu.

Adapun penggunaaan alat dan bahan yang digunakan dalam penelitian ini adalah cangkul, sabit, gunting, tali rafia, rol meter/meteran, timbangan, dan mistar.Bahan yang akan digunakan adalah rumput Odot (Pennisetum purpureum $C v$. Mott) dan mulsa kulit kopi. Desa Tugu Rejo Kecamatan Kabawetan Kabupaten Kepahiang Provinsi Bengkulu.

Pada tahapan penelitian ini menggunakan rumput Odot (Pennisetum purpureum $C v$. Mott) yang baru ditanam dengan jarak tanamyaitu 75 x $75 \mathrm{~cm}$. Dalam penelitian ini telah dilaksanakan beberapa tahapan diantaranya yaitu persiapan lahan, pengolahan lahan secara manual, membuat lubang tanam, pemupukan rumput Odot (Pennisetum purpureum $C v$. Mott), penanaman rumput pemupukan rumput Odot (Pennisetum purpureum Cv. Mott) pengukuran pertumbuhan dan pengukuran produksi.

\section{Persiapan dan Pengolahan Lahan}

Persiapan lahan merupakan langkah awal dalam penelitian ini setelah semua alat dan bahan dipersiapkan.Persiapan lahan meliputi yaitu pembersihan lahan yang masih terdapat tanaman-tanamanyang dapat mengganggu dalam pertumbuhan rumput Odot (Pennisetum purpureum Cv. Mott).AAK (2003) melaporkan bahwa pembersihan areal (Land-clearing) bertujuan membersihkan areal tersebut terhadap pepohonan, semak-semak dan alang-alang atau tumbuhan lainnya dengan mempertimbangkan beberapa jenis pepohonan sebagai pelindung, peneduh dan pencegah erosi.

Pada tahap selanjutnya yaitu pengolahan lahan secara manual, dengan menggunakan cangkul dan penggaruk tanah sebagai alat dalam pengolahan lahan ini, yang bertujuan untuk menggemburkan tanah sehingga menjadi media yang siap di tanam.

Pembuatan lubang tanam bertujuan untuk mempermudah penanaman, menyediakan tempat bagi akar tanaman dan menyediakan lingkungan perakaran yang baik untuk rumput Odot (Pennisetum purpureum $C v$. Mott).

Pemupukan dalam penelitian ini menggunakan pupuk organik yang berasal dari pupuk kandang yaitu feses sapi sebagai media pupuk dan mulsa kulit kopi dalam media penutup tanah. Pemupukan dilakukan sebelum penanaman bibit rumput odot, yang diberikan pada setiap lobang pada lubang tanam yaitu dengan ukuran $75 \times 75 \mathrm{~cm}$ dengan 24 satuan percobaan.

Reksohadiprodjo (1994) dan Regan(1997) melaporkan pemilihan bibit rumput Odot dibudidayakan dengan potongan batang (stek) atau sobekan rumpun (pols) sebagai bibit. Bahan stek berasal dari batang yang sehat dan tua, dengan panjang stek $20-25 \mathrm{~cm}(2-3$ ruas atau paling sedikit 2 buku atau mata).

Menurut Dapa (2016) bibit tanaman rumput Odot (Pennisetum pupureum $C v$. Mott) dalam bentuk stek ditanam sedalam 2 $\mathrm{cm}$.

Penanaman rumput Pennisetum
purpureum $\quad C v$. Mott menggunakan penanaman untuk memperbanyak tanaman yaitu dengan cara vegetatif atau dengan stek batang.

Pemberian mulsa kulit kopi di berikan dengan cara penebaran dengan ketebalan $2 \mathrm{~cm}$ pada setiap perlakuan. 


\section{Rancangan dan Variabel Penelitian}

Penelitian ini menggunakan

Rancangan Acak Kelompok (RAK), dengan

4 (empat) perlakuan dan 6 (enam) ulangan.

Semua perlakuan menggunakan mulsa setebal $2 \mathrm{~cm}$, perlakuan yang diuji terdiri atas sebagai berikut :

P0 = Pupuk kandang feses sapi kadar 0 ton/ha.

P1 = Pupuk kandang feses sapi kadar 10 ton/ha.

P2 = Pupuk kandangfeses sapi kadar 15 ton/ha.

P3 = Pupuk kandang feses sapi kadar 20 ton/ha.

Model matematika rancangan (Nugroho, 2008)adalah :

$$
Y_{i j}=\mu_{+\tau i+\varepsilon j(i)}
$$

Keterangan,

$Y i j=$ nilai pengamatan pada perlakuan ke- $\mathrm{i}$ dan ulangan ke- $\mathrm{j}$

$\mu \quad=$ nilai rataan umum

$\tau i=$ pengaruh perlakuan ke- $\mathrm{i}$

$\varepsilon j(i)=$ penyimpangan perlakuan ke- $\mathrm{i}$ dan ulangan ke- $\mathrm{j}$ dari rataanperl akuan

$i \quad=$ perlakuan 4 (empat)

$j \quad=$ ulangan 6 (enam)

\section{Pertumbuhan Rumput Odot}

Pertumbuhan dari rumput Odot (Pennisetum purpureum $C v$. Mott) yang diamati meliputi panjang daun, lebar daun, tinggi tanaman dan jumlah tunas yang dilakukan dengan pengukuran setiap 14 hari sekali, pengukuran meliputi :

\section{Tinggi Tanaman}

Diukur pada batang tanaman tertinggi dimulai dari pangkal batang (permukaan tanah) sampai titik tumbuh tanaman (ujung daun yang lurus ke atas sejajar batang) mengacu pada pendapat Zahroh et al. (2016) dengan menggunakan mistar dan diamati dua minggu sekali.

\section{Jumlah tunas/anakan}

Perhitungan jumlah anakan dengan menghitung banyaknya anakan yang tumbuh dalam setiap rumpunnya dan diamati 2 minggu sekali.

\section{Panjang daun}

Pengukuran panjang daun dari pangkal daun sampai ke ujung daun pada bagian daun dan diamati dua minggu sekali. Dengan pengukuran 1 helai daun dengan melihat yang paling panjang lalu diberi tanda sebagai penanda.

\section{Lebar daun}

Pengukur lebar daun menggunakan bagian daun terlebar dari sisi satu ke sisi yang lainnya dan diamati dua minggusekali.

\section{Produksi hijauan}

Pengukuran produksi Pennisetum purpureum $C v$. Mott dengan memanen hijauan tersebut setiap petaknya kemudian ditimbang berapa berat segarnya. Selanjutnya diambil sampel sebanyak $10 \%$ dari berat segardan kemudian dilakuakan pengeringan dengan matahari hingga beratnya konstan. Sampel digiling dengan diameter saring 1 mm untuk dianalisis kadar air dan BK nya. kemudian dimasukkan dalam oven dengan suhu $105^{\circ} \mathrm{C}$ selama \pm 8 jam dan ditimbang hasilnya untuk mengukur bahan kering hijauan.

\section{Variabel pendukung}

Variabel pendukung yang diamati selama penelitian berlangsung meliputicurah hujan, temperatur udara, kelembaban udara danintensitas cahaya matahari yang diukur selama penelitian berlangsung. Datadari variabel pendukung yang terdiridaricurah hujan, temperatur udara, kelembaban udara dan intensitas cahaya matahari akan didapat dari BMKG Stasiun Geofisika Kabupaten Kepahiang, Provinsi Bengkulu.

\section{Analisis Data}

Data yang diperoleh akandianalisis dengan menggunakan (ANOVA) untuk mengetahui ada tidaknya pengaruh perlakuan, apabila terdapat perbedaan nyata $\mathrm{P}<0,05$ dilanjutkan dengan Duncan's Multiple Range Test (DMRT) untuk melihat perbedaan antar perlakuan menggunakan 
program Software SPSS 16.0 (Nugroho, 2008)

\section{HASIL DAN PEMBAHASAN}

\section{Keadaan Lokasi Penelitian}

Letak Geografis penelitian ini berada pada koordinat $3^{\circ} 39^{\prime} 00.71$ LS $102^{\circ} 35^{\prime} 20.81$ BT. Adapun data iklim pada saat penelitian yaitu tertera pada Tabel 1 :

Rata-rata temperatur udara berkisar 23,53 - 24,12. Menurut Mannetje dan Jones (1992) suhu yang paling baik untuk pertumbuhan tanaman rumput jenis gajah antara $25-40{ }^{\circ} \mathrm{C}$. Curah hujan pada 3 bulan penelitian tergolong rendah. Menurut BMKG Nasional (2010) rata-rata curah hujan tergolong rendah 5-20 mm, sedang 20-50 $\mathrm{mm}$, tinggi 50-100 $\mathrm{mm}$ dan sangat tinggi $>100 \mathrm{~mm}$. Menurut Mcllroy (1977) hujan yang terlalu tinggi mempercepat pengikisan unsur hara tanah di lahan terbuka, sehingga produktivitas tanaman menjadi rendah.

Tabel 2 merupakan hasil analisis tanah sebelum dilakukan penelitian dan sesudah melakukan penelitian.
Hasil analisis tanah unsur N, P, dan $\mathrm{K}$ menunjukan peningkatan dari sebelum di lakukannya penelitian dan sesudah dilakukannya penelitian. Menurut Kartasapoetra dan Sutejo (2005) pupuk kandang bermanfaat untuk meningkatkan kesuburan tanah, mempertinggi kadar humus, memperbaiki struktur tanah, mendorong kehidupan jasad renik, sebagai sumber unsur makro dan mikro yang dibutuhkan tanaman sehingga keseimbangan unsur hara di dalam tanah menjadi lebih baik.

\section{Pertumbuhan Rumput Odot (Pennisetum purpureum Cv. Mott)}

Hasil sidik ragam menunjukkan bahwa perlakuan tidak berpengaruh nyata $(\mathrm{P}>0,05)$ terhadaptinggi tanaman. Pengukuran tinggi tanaman setiap minggunya berbeda pada minggu ke-2 berkisar 27,86 - 30,79 cm dan pada minggu ke-8 berkisar 65,06 -68,64 cm. Rata-rata pertumbuhan rumput Odot (Pennisetum purpureum $C v$. Mott), terdapat pada tabel 3.

Tabel 1. Data rata-rata iklim, curah hujan, intensitas penyinaran matahari, suhu dan kelembaban

\begin{tabular}{|c|c|c|c|}
\hline \multirow{2}{*}{ Parameter Iklim } & \multicolumn{3}{|c|}{ Bulan } \\
\hline & Oktober & November & Desember \\
\hline $\begin{array}{l}\text { Intensitas cahaya } \\
\text { matahari }(\%)\end{array}$ & 52,23 & 34,21 & 39,52 \\
\hline Temperatur udara $\left({ }^{\circ} \mathrm{C}\right)$ & 24,12 & 24,06 & 23,53 \\
\hline Curah hujan (mm) & 13,06 & 14,21 & 12,49 \\
\hline Kelembaban (\%) & 85,10 & 86,90 & 87,87 \\
\hline \multicolumn{4}{|c|}{ Sumber : BMKG Stasiun Geofisika Kabupaten Kepahiang (2018) } \\
\hline \multicolumn{4}{|c|}{ Tabel 2. Unsur N, P, dan K tanah } \\
\hline \multirow{2}{*}{ Tanah } & \multicolumn{3}{|c|}{ Unsur } \\
\hline & $\mathrm{N}(\%)$ & $\mathrm{P}(\mathrm{ppm})$ & $\mathrm{K}(\mathrm{me} / 100 \mathrm{~g})$ \\
\hline Sebelum & 0,52 & 0,12 & 0,27 \\
\hline Sesudah & 0,66 & 0,22 & 3,03 \\
\hline
\end{tabular}

Sumber : Laboraturium Tanah BPTP Bengkulu (2018) 
Tabel 3. Rata-rata tinggi tanaman $(\mathrm{cm})$ rumput Odot

\begin{tabular}{ccccc}
\hline $\begin{array}{c}\text { Rata-rata Tinggi } \\
\text { Tanaman } \\
\text { Minggu }\end{array}$ & P0 & P1 & P2 & P3 \\
\cline { 2 - 5 } & $13,00 \pm 0,00^{\mathrm{a}}$ & $13,00 \pm 0,00^{\mathrm{a}}$ & $13,00 \pm 0,00^{\mathrm{a}}$ & $13,00 \pm 0,00^{\mathrm{a}}$ \\
2 & $27,86 \pm 5,29^{\mathrm{a}}$ & $30,79 \pm 10,60^{\mathrm{a}}$ & $28,72 \pm 5,24^{\mathrm{a}}$ & $30,25 \pm 9,43^{\mathrm{a}}$ \\
4 & $40,56 \pm 6,08^{\mathrm{a}}$ & $44,38 \pm 5,38^{\mathrm{a}}$ & $43,32 \pm 7,23^{\mathrm{a}}$ & $44,46 \pm 10,97^{\mathrm{a}}$ \\
6 & $54,50 \pm 6,38^{\mathrm{a}}$ & $55,60 \pm 5,09^{\mathrm{a}}$ & $55,90 \pm 5,96^{\mathrm{a}}$ & $55,48 \pm 7,39^{\mathrm{a}}$ \\
8 & $65,06 \pm 7,08^{\mathrm{a}}$ & $68,27 \pm 8,35^{\mathrm{a}}$ & $68,64 \pm 8,35^{\mathrm{a}}$ & $67,28 \pm 8,11^{\mathrm{a}}$ \\
\hline
\end{tabular}

Keterangan: Superscript yang sama pada baris yang sama menunjukkan perbedaan yang tidak nyata $(\mathrm{P}>0,05)$. P0 (kontrol), P1 (pupuk feses sapi 10 ton/ha), P2 (pupuk feses sapi 15 ton/ha), P3 (pupuk feses sapi 20 ton/ha).

Rata-rata tinggi tanaman rumput Odot ini lebih tinggi dibandingkan dengan Sirait et al. (2013) yaitu 40,3 cm pada umur pemotongan 30 hari di daerah dataran tinggi Siborong-borong. Budiono (2018) melaporkan penggunakan pupuk feses sapi dengan 3 kali pemupukan tinggi tanaman rumput Odot dapat mencapai 74,02 $\mathrm{cm}$ pada umur potong 60 hari.

Menurut Wijaya (2008) pemberian pupuk organik pada kotoran ternak terdapat unsur hara yang rendah untuk memenuhi kebutuhan tanaman secara cepat sehingga lambat tersedia bagi tanaman. Pada penelitian Polakitan dan Kairupan (2009) dilaporkan bahwa tinggi tanaman rumput Odot bisa mencapai 111,68 cm dengan umur potong 40 HSP (Hari Setelah Pemotongan). Lukas (2017) pemberian pupuk Nitrogen 92368/ha tinggi rumput Odot bisa mencapai $151,83-172,72 \mathrm{~cm}$ dengan umur pemotongan 90 hari. Menurut Sawen (2012) intensitas cahaya dan jenis rumput memberikan respons yang berbeda terhadap pertumbuhan tanaman secara khusus tinggi tanaman dan jumlah anakannya.

\section{Panjang Daun}

Hasil sidik ragam menunjukkan bahwa perlakuan tidak berpengaruh nyata $(\mathrm{P}>0,05)$ terhadap panjang daun pada semua perlakuan. Pengukuran Panjang daun setiap minggunya berbeda pada minggu ke-2 berkisar 19,04 - 21,97 cm dan pada minggu ke- 8 berkisar 49,17-51,94 cm. Panjang daun pada penelitian Sirait et al. (2013) rumput Odot $40,6 \mathrm{~cm}$ pada pemotongan 30 hari di daerah dataran tinggi Siborong-borong. Hal tersebut bisa terjadi karena pengaruh ketinggian tempat pada daerah Siborongborong 1.416 Mdpl sedangkan di daerah penelitian adalah 1000-1100 Mdpl. Menurut Budiono (2018) pemberian pupuk feses sapi sebanyak 3 kali pemupukan panjang daun rumput Odot dapat mencapai $57,04 \mathrm{~cm}$ dengan umur potong 60 hari.

Tabel 4. Rata-rata panjang daun $(\mathrm{cm})$ rumput Odot

\begin{tabular}{ccccc}
\hline $\begin{array}{c}\text { Rata-rata } \\
\text { Panjang Daun } \\
\text { Minggu }\end{array}$ & P0 & P1 & P2 & P3 \\
\cline { 2 - 5 } & $19,04 \pm 5,24$ & $21,97 \pm 9,56$ & $19,31 \pm 5,03$ & $19,73 \pm 8,82$ \\
4 & $31,28 \pm 5,98$ & $34,03 \pm 4,50$ & $31,52 \pm 7,01$ & $32,85 \pm 10,37$ \\
6 & $41,84 \pm 5,65$ & $42,42 \pm 4,12$ & $41,63 \pm 5,01$ & $41,84 \pm 6,67$ \\
8 & $49,17 \pm 6,17$ & $51,67 \pm 6,39$ & $51,94 \pm 6,78$ & $51,25 \pm 6,54$ \\
\hline
\end{tabular}

Keterangan: Superscript yang berbeda pada baris yang sama menunjukkan perbedaan yang tidak nyata $(\mathrm{P}>0,05)$. P0 (kontrol), P1 (pupuk feses sapi 10 ton/ha), P2 (pupuk feses sapi 15 ton/ha), P3 (pupuk feses sapi 20 ton/ha). 


\section{Lebar Daun}

Tabel 5. Rata-rata lebar daun $(\mathrm{cm})$ rumput Odot

\begin{tabular}{ccccc}
\hline $\begin{array}{c}\text { Rata-rata Lebar } \\
\text { Daun } \\
\text { Minggu }\end{array}$ & P0 & P1 & P2 & P3 \\
\cline { 2 - 5 } & $1,38 \pm 0,33^{\mathrm{a}}$ & $1,74 \pm 0,41^{\mathrm{bc}}$ & $1,87 \pm 0,41^{\mathrm{c}}$ & $1,53 \pm 0,29^{\mathrm{ab}}$ \\
2 & $1,73 \pm 0,28^{\mathrm{a}}$ & $2,10 \pm 0,33^{\mathrm{b}}$ & $2,11 \pm 0,27^{\mathrm{b}}$ & $1,98 \pm 0,26^{\mathrm{b}}$ \\
6 & $1,97 \pm 0,33^{\mathrm{a}}$ & $2,22 \pm 0,23^{\mathrm{b}}$ & $2,23 \pm 0,15^{\mathrm{b}}$ & $2,20 \pm 0,19^{\mathrm{b}}$ \\
8 & $2,20 \pm 0,29^{\mathrm{a}}$ & $2,39 \pm 0,45^{\mathrm{b}}$ & $2,50 \pm 0,20^{\mathrm{b}}$ & $2,40 \pm 0,15^{\mathrm{b}}$ \\
\hline
\end{tabular}

Keterangan: Superscript yang berbeda pada baris yang sama menunjukkan perbedaan yang nyata $(\mathrm{P}<0,05)$. $\mathrm{P} 0$ (kontrol), P1 (pupuk feses sapi 10 ton/ha), P2 (pupuk feses sapi 15 ton/ha), P3 (pupuk feses sapi 20 ton/ha).

Hasil sidik ragam menunjukkan bahwa perlakuan berpengaruh nyata $(\mathrm{P}<0,05)$ terhadap lebar daun. Pengukuran lebar daun setiap minggunya berbeda pada minggu ke-2 berkisar 1,38-1,87 cm dan pada akhir pengukuran berkisar 2,20-2,44 $\mathrm{cm}$. Hasil uji lanjut menunjukan pada minggu kedua perlakuan P0 dan P3 mempunyai lebar daun yang tidak berbeda, namun berbeda dengan $\mathrm{P} 1$ dan $\mathrm{P} 2$. pada P1 dan P2 mempunyai lebar daun yang sama. Pada minggu ke 4,6 , dan 8 perlakuan P3, P2 dan P1 berpengaruh nyata $(\mathrm{P}<0,05)$ dengan perlakuan $\mathrm{P} 0$. Lebar daun pada penelitian ini lebih tinggi dibandingkan dengan penelitian Sirait et al. (2013) dengan rata-rata lebar daun $1,6 \mathrm{~cm}$ pada pemotongan 60 hari didaerah dataran tinggi Siborongborong. Lebar daun ini hampir sama pada penelitian Sarwanto dan Tuswati (2017) dengan rata- rata lebar daun RGK (Rumput Gajah Kerdil + kacang tanah) $25 \mathrm{~mm}$ atau 2,5 $\mathrm{cm}$.

Menurut Haryanto (2007) pemberian unsur Nitrogen yang tinggi juga berfungsi untuk memacu proses pembentukan daun tanaman rumput gajah, karena nitrogen merupakan unsur hara pembentuk asam amino dan protein sebagai bahan dasar tanaman dalam penyusunan daun. Hal ini didukung oleh Setiawan (2002) bahwa kotoran sapi memiliki unsur hara $0,40 \% \mathrm{~N} ; 0,20 \% \mathrm{P} ; 0,10 \% \mathrm{~K}$.

\section{Jumlah Anakan}

Berdasarkan hasil sidik ragam menunjukkan bahwa perlakuan berpengaruh sangat nyata $(\mathrm{P}<0,01)$ terhadap jumlah anakan. Hasil uji lanjut menunjukkan P2 berbeda sangat nyata $(\mathrm{P}<0,01)$ dengan $\mathrm{P} 3, \mathrm{P} 1$ dan $\mathrm{P} 0$, sedangkan $\mathrm{P} 0$ menunjukkan jumlah anakan terendah dibandingkan dengan P1 dan P3. Jumlah anakan ini lebih tinggi dibandingkan dengan penelitian Budiono (2018) pemberian pupuk feses sapi sebanyak 3 kali pemupukan rata-rata jumlah anakan 3,75 batang pada umur pemotongan 60 hari.

Tabel 6. Rata-rata jumlah anakan (batang) rumput.

\begin{tabular}{ccccc}
\hline $\begin{array}{c}\text { Rata-rata Jumlah } \\
\text { Anakan } \\
\text { Minggu }\end{array}$ & P0 & P1 & P2 & P3 \\
\cline { 2 - 5 } & $1,00 \pm 0,00^{\mathrm{a}}$ & $1,29 \pm 0,46^{\mathrm{ab}}$ & $1,61 \pm 0,70^{\mathrm{b}}$ & $1,28 \pm 0,46^{\mathrm{ab}}$ \\
2 & $1,28 \pm 0,46^{\mathrm{a}}$ & $1,56 \pm 0,51^{\mathrm{ab}}$ & $2,22 \pm 0,94^{\mathrm{c}}$ & $1,83 \pm 0,62^{\mathrm{ab}}$ \\
6 & $1,67 \pm 0,48^{\mathrm{a}}$ & $2,39 \pm 0,50^{\mathrm{b}}$ & $3,22 \pm 1,16^{\mathrm{c}}$ & $2,28 \pm 0,83^{\mathrm{bc}}$ \\
8 & $2,50 \pm 0,51^{\mathrm{a}}$ & $3,11 \pm 0,67^{\mathrm{b}}$ & $4,00 \pm 0,82^{\mathrm{c}}$ & $3,33 \pm 0,97^{\mathrm{b}}$ \\
\hline
\end{tabular}

Keterangan: Superscript yang berbeda pada baris yang sama menunjukkan perbedaan yang sangat nyata $(\mathrm{P}<0,01)$. P0 (kontrol), P1 (pupuk feses sapi 10 ton/ha), P2 (pupuk feses sapi 15 ton/ha), P3 (pupuk feses sapi 20 ton/ha). 
Menurut Wong (1991) yang disitasi oleh Putra et al. (2014) cahaya matahari yang masuk pada lahan sangat berpengaruh kepada tiller/ anakan tanaman yaitu semakin tinggi cahaya matahari maka semakin banyak jumlah anakannya. Hal tersebut ditambah dengan Sabihan (1989) dalam Hidayah (2003) pemberian pupuk kandang pada lahan akan meningkatkan struktur pada tanah dalam meningkatkan pertumbuhan akar tanaman dari pori-pori tanah sehingga memudahkan tunas-tunas baru tumbuh menembus permukaan tanah.

Dari data jumlah rata-rata anakan dapat dilihat bahwa rata-rata jumlah anakan berkisar $1-4$ batang. Syamsuddin (2016) pemberian pupuk organik cair Sedarisa dapat mencapai jumlah anakan berkisar 8-13 batang/10 $\mathrm{m}^{2}$ dengan umur potong $40 \mathrm{HSP}$ (hari setelah pemotongan).

\section{Tinggi Tanaman, Lebar Daun, Panjang} Daun, dan Jumlah Anakan

Berikut merupakan grafik tinggi tanaman, lebar daun, panjang daun dan jumlah anakan tertera pada grafik 1 :

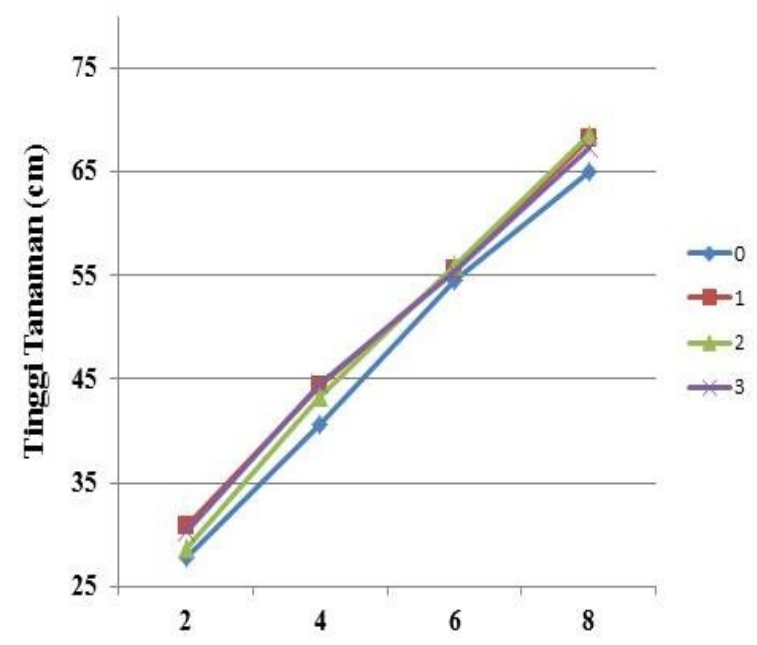

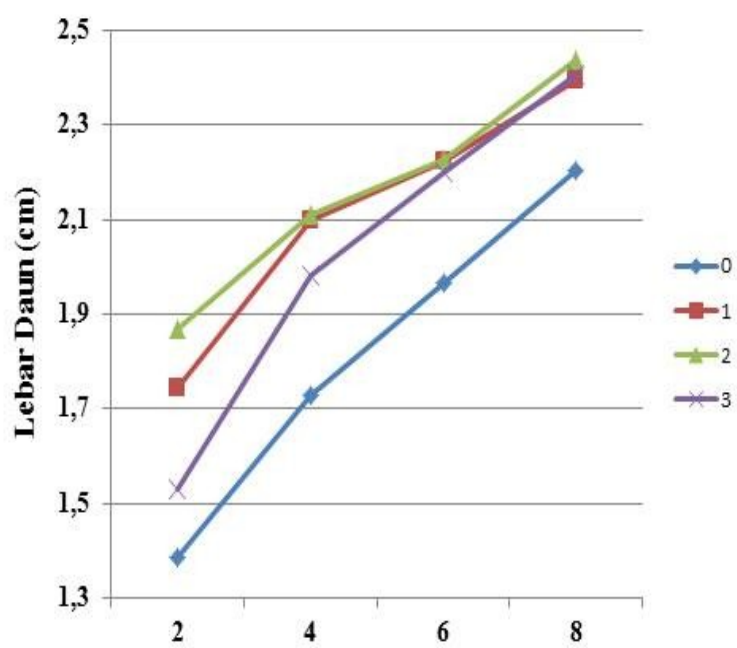
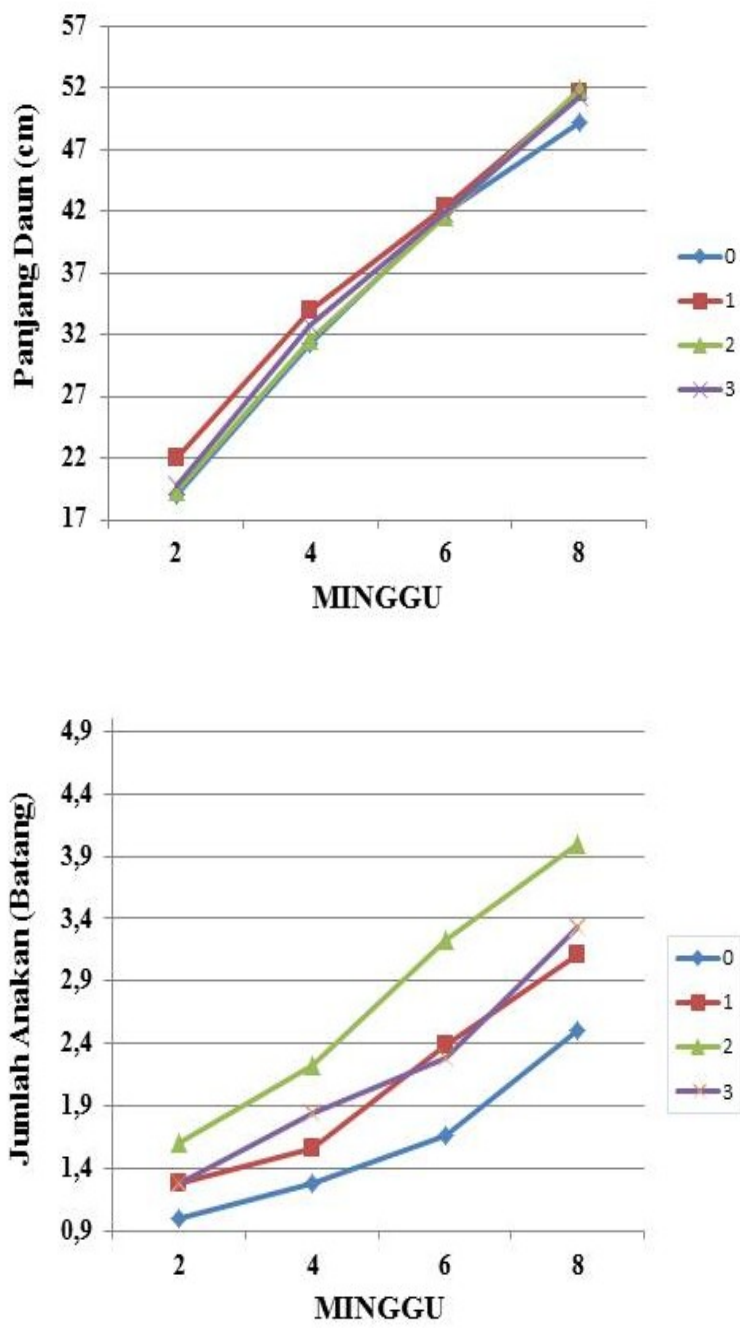

Grafik 1. Tinggi tanaman, panjang daun, lebar daun dan jumlah anakan rumput

Pada Grafik 1 terlihat bahwa pada akhir pengukuran rata-rata tinggi tanaman, lebar daun, panjang daun dan jumlah anakan 
memiliki data yang berbeda. Pada tinggi batang yang tertinggi pada P2 $68,64 \mathrm{~cm}$, lebar daun yang terlebar pada $\mathrm{P} 22,5 \mathrm{~cm}$, panjang daun yang terpanjang pada $\mathrm{P} 251,94$ $\mathrm{cm}$ dan jumlah anakan yang terbanyak pada P2 4 batang. Hal ini juga berpengaruh terhadap produksi segar yang dihasilkan setiap perlakuan. Berikut merupakan grafik produksi segar $\left(\mathrm{g} / \mathrm{m}^{2}\right)$, tertera pada grafik 2 :

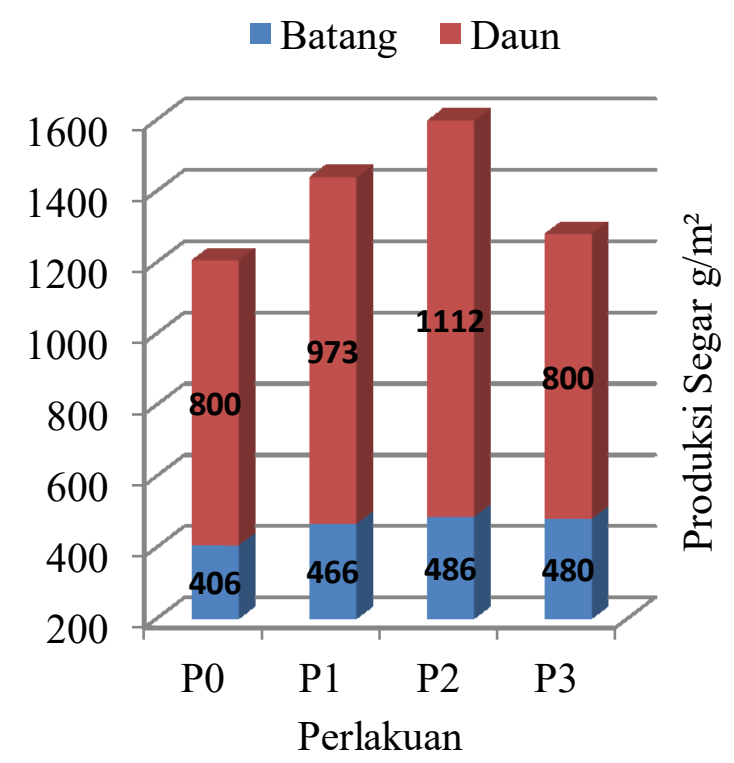

Grafik 2. Produksi segar rumput Odot

Terlihat pada Gambar 2, bahwa produksi segar rumput Odot pada perlakuan P2 memiliki produksi yang lebih tinggi dibandingkan P0, P1 dan P3. Produksi pada perlakuan P2 sebesar $1598 \mathrm{gr} / \mathrm{m}^{2}$. Produksi segar pada penelitian ini lebih tinggi dibandingkan dengan penelitian Zahroh et al. (2016) dengan produksi rumput Odot berkisar 86,11-219,44 gram dengan umur potong 30 hari. Menurut Budiono (2018) dengan 3 kali pemberian pupuk feses sapi, sebesar 2598 gram/petakdan Dapa (2016) produksi segar $5,68 \quad-7,83 \mathrm{~kg}$ dengan pemberian Pupuk Urea, Biourin dan Kombinasinya pada pemotongan ketiga. Menurut Lasamadi et al. (2013) pemberian pupuk pada tanaman juga memiliki batas optimal.

Pada Gambar 2 terlihat bahwa produksi segar batang dan daun P0 (kontrol) memiliki produksi segar yang rendah dibandingkan dengan perlakuan P1, P2 dan P3.. Menurut Ifradi dan Elsifitriana (2003) pupuk kandang dapat mempertahankan bahan organik tanah, meningkatkan aktivitas biologis dan juga meningkatkan ketersediaan air tanah. Semakin tinggi kadar air tanah maka penyerapan dan perpindahan unsur hara maupun air akan lebih baik, sehingga laju fotosintesis untuk dapat menghasilkan cadangan makanan bagi pertumbuhan tanaman lebih terjamin dan produksipun akan meningkat.

\section{Produksi Bahan Kering}

Hasil sidik ragam menunjukkan perlakuan berbeda sangat nyata $(\mathrm{P}<0,01)$. Produksi berat kering rumput Odot dengan pemberian pupuk feses sapidengan dosis yang berbeda memberikan pengaruh yang berbeda. Hasil uji lanjut BK batang menunjukan bahwa P3, P2 dan P1 berbeda nyata $(\mathrm{P}<0,05)$ dengan $\mathrm{P} 0$ dan $\mathrm{BK}$ daun $\mathrm{P} 2$ berbeda sangat nyata $(\mathrm{P}<0,01)$ terhadap $\mathrm{P} 1$, P3 dan P0.

Tabel 7. Rata-rata produksi bahan kering batang dan daun rumput Odot

\begin{tabular}{crrrr}
\hline \multirow{2}{*}{ Produksi } & P0 & P1 & Perlakuan & P3 \\
\cline { 2 - 5 } & & & gram $/ \mathrm{m}^{2}$ \\
BK Batang & $10,48 \pm 2,13^{\mathrm{a}}$ & $15,58 \pm 3,12^{\mathrm{b}}$ & $17,72 \pm 4,57^{\mathrm{b}}$ & $15,35 \pm 3,24^{\mathrm{b}}$ \\
& & & & \\
BK Daun & $29,13 \pm 4,11^{\mathrm{a}}$ & $41,41 \pm 3,83^{\mathrm{b}}$ & $49,48 \pm 7,46^{\mathrm{c}}$ & $30,17 \pm 5,04^{\mathrm{a}}$
\end{tabular}

Keterangan: Superscript yang berbeda pada baris yang sama menunjukkan perbedaan yang sangat nyata $(\mathrm{P}<0,01)$. P0 (kontrol), P1 (pupuk feses sapi 10 ton/ha), P2 (pupuk feses sapi 15 ton/ha), P3 (pupuk feses sapi 20 ton/ha). 
Produksi rata-rata $\mathrm{BK}$ batang rumput Odot 10,48 - 17,72 gram $/ \mathrm{m}^{2}$ dan rata-rata BK daun rumput Odot 29,13 - 49,48 gram $/ \mathrm{m}^{2}$. Terlihat pada perlakuan P2 (15 ton pupuk feses sapi + mulsa kulit kopi) memberikan produksi berat kering yang lebih baik dibandingkan dengan perlakuan yang lainnya. Penelitian ini lebih tinggi dibandingkan Novita et al. (2014) berat kering rumput odot 26,51 - 33,06 gram/petak atau $10,60-13,22 \mathrm{gram} / \mathrm{m}^{2}$ dengan menggunakan pupuk kimia (TSP, $\mathrm{KCl}$ dan Urea).

Menurut Syofiarni (1982) dalam Mega (2012) produksi suatu tanaman selalu disebabkan adanya petumbuhan dari rumput seperti betambahnya tinggi dan juga bertambahnya jumlah anakan. Hakim et al. (2007), pemberian unsur hara yang lengkap pada tanaman memberikan pengaruh produktifitas dan pertumbuhan suatu tanaman. Pendapat tersebut didukung oleh Rismunandar (1993) bahwa kesuburan tanah dapat menentukan kapasitas produksi tanaman.Karena kesuburan tanah mempunyai peranpenting dalam menentukan tinggi rendanya produktivitas tanaman. Dapa (2016) menyatakan bahwa selain unsur hara, produksi rumput Gajah Kate juga dipengaruhi oleh faktor lingkungan dan iklim.

\section{KESIMPULAN}

Berdasarkan hasil penelitian ini dapat disimpulkan bahwa perlakuan pemberian pupuk feses sapi dengan dosis 15 ton/ha dan mulsa kulit kopi lebih baik terhadap lebar daun, jumlah anakan dan bahan kering rumput Odot (Pennisetum purpureum Cv.Mott).

\section{DAFTAR PUSTAKA}
AAK. 1983. Hijauan Makanan Ternak Potong, Kerja dan Perah. Kanisius, Yogyakarta.

AAK. 2003. Hijauan Pakan Ternak Potong, Kerja dan Perah. Yayasan Kanisius, Yogyakarta.

Ako, A. 1997. Pengaruh Tingkat Pemberian Pupuk Kandang Terhadap Pertumbuhan dan Produksi Rumput Gajah (Pennisetum purpureum Schumach) dan Sorgum (Sorghum bicolor Moench). Jurnal Veteriner 4 (2):35-42.

Aminudin, S. 1990. Beberapa Jenis dan Metode Pengawetan Hijauan Pakan Ternak Tropik.Universitas Jenderal Soedirman, Purwokerto.

BMKG.2010. Kondisi Cuaca Ekstrem dan Iklim. BMKG, Jakarta.

BMKG Stasiun Geofisika. 2018. Data iklim curah hujan, intensitas penyinaran matahari, suhu dan kelembaban. Stasiun Geofisika, Kepahiang.

BPS Kabupaten Kepahiang. 2017. https://kepahiangkab.bps.go.id/. Diakses Tanggal 22 februari 2018.

Budiono. 2018. Produktivitas Rumput Odot (Pennisetum purpureum $\mathrm{Cv}$ Mott) dengan Pemberian Jenis Pupuk yang Berbeda. Universitas Bengkulu, Bengkulu.

Dapa, D. S. U. N. 2016. Pengaruh Pemberian Pupuk Urea, Biourine dan Kombinasinya terhadap Tingkat Produktifitas Rumput Gajah Kate (Pennisetum purpureum Cv. Mott) pada Setiap Umur Pemotongan. Skripsi. Program Sarjana Program Studi Peternakan Jurusan Peternakan Fakultas Pertanian Universitas Warmadewa, Denpasar.

Hakim, N., N. Yusuf, A. Lubis, G.N. Sutopo, D. Amin, G.B. Hong dan H.H. Bailey. 2007. Dasar-Dasar Ilmu Tanah. Universitas Lampung, Lampung. 
Haryanto. 2007. Kecukupan pakan ternak solusi menuju ketahanan pangan nasional. Bahan Orasi Pengukuhan Peneliti Utama sebagai Profesor Riset Bidang Nutrisi Ruminansia. Badan Penelitian dan Pengembangan Pertanian, Jakarta.

Hidayah. 2003. Kajian Penggunaan Pupuk PHONSKA Terhadap Pertumbuhan dan Produksi Rumput Raja (King Grass). Institut Pertanian Bogor, Bogor.

Hillel, D. 1980. Application of Soil Physics. Academic Press, New York.

Ifradi., P. dan Elsifitriana. 2003. Pengaruh Pemberian Pupuk Kandang dan Mulsa Jerami Padi terhadap Produksi dan Nilai Gizi Rumput Raja pada Tanah Podzolik Merah Kuning, Peternakan dan Lingkungan. Universitas Andalas, Padang.

Kartasapoetra, A. G., dan M. M. Sutedjo. 2005. Pengantar Ilmu Tanah. PT. Rineka Cipta, Jakarta.

Lasamadi R. D., Malalantang S. S, Rustandi dan S. D. Anis. 2013. Pertumbuhan dan perkembangan rumput gajah dwarf (Pennisetum purpureum cv. Mott) yang diberi pupuk organik hasil fermentasi EM4. Jurnal Zootek 32 (5):158-171.

Lukas, Ricky G., David. A. K., dan M. Najoan. 2017. Karakter Morfologi dan Kandungan Nutrien Rumput Gajah Dwarf (Pennisetum purpureum cv. Mott) pada Naungan dan Pemupukan Nitrogen. Jurnal LPPM Bidang Sains dan Teknologi 4 (2): 33-43.

Mega, R. S. 2012. Produksi dan Nilai Nutrisi Rumput Gajah (Pennisetum purpureum) Cv. Taiwan yang Diberi Dosis Pupuk N, P, K Berbeda pada Lahan Kritis Tambang Batubara. Universitas Andalas, Padang.
Mannetje, L. and R.M. Jones. 1992. Plant Resources of South-East Asia no 4. Forages. Prosea, Bogor.

Novizan. 2005. Petunjuk pemupukan yang Efektif. PT. Agromedia Pustaka, Jakarta.

Nugroho, S. 2008. Dasar-dasar Rancangan Percobaan.UNIB Press, Bengkulu.

Syamsuddin, St. N. 2016. Pertumbuhan Kembali (Regrowth) Rumput Gajah Mini (Pennisetum purpureum Cv.Mott) Melalui Pemberian Pupuk Organik Cair Pada Lahan Kering-Kritis. Skripsi. Universitas Hasanuddin, Makassar.

Polakitan, D. dan A. Kairupan. 2009. Pertumbuhan dan Produktivitas Rumput Gajah Dwarf (Pennisetum purpureum cv. Mott) pada Umur Potong Berbeda. Balai Pengkajian Teknologi Pertanian, Sulawesi Utara.

Purwowidodo.1983. Teknologi Mulsa. Dewaruci, Jakarta.

Putra, W. A. A. P., Adi, P. IG. B., Wirawan, I. W., Sumardani, N. L. G., dan Suberata, I W. 2014. Respons Rumput Gajah (Pennisetum purpureum Schumach) terhadap Aplikasi Pupuk Urea, Kotoran Ayam, dan Kotoran Sapi sebagai Sumber Nitrogen (N). Majalah Ilmiah Peternakan.17(2) : 41-45

Rachmawati, M. dan Mashur. 2000. Pupuk Bokashi. Lembaga Ilmu Pengetahuan Indonesia, Jakarta.

Regan, C.S. 1997. Forage Conservation in The Wet/Dry Tropics for Small Landholder Farmers. Thesis. Faculty of Science Nothern Territory University, Australia.

Reksohadiprodjo, S. 1994. Produksi Tanaman Hijauan Makanan Ternak Tropik. Universitas Gadjah Mada.Yogyakarta. 
Rismunandar, 1993. Tanah Seluk beluknya bagi Pertanian.Sinar Baru Aglensindo, Bandung.

Rukmana, R.. 2005. Rumput Unggul Hijauan Makanan Ternak. Kanisius (Anggota IKAPI). Jakarta.

Sawen, D. 2012. Pertumbuhan Rumput Gajah (Pennisetum purpureum) dan Benggala (Panicum maximum) akibat Perbedaan Intensitas Cahaya. Agrinimal Jurnal Ilmu Ternak dan Tanaman 2 (1): 17-20.

Sarwanto, D. dan S. E. Tuswati.2017. Pertumbuhan Rumput Gajah Kerdil (Pennisetum purpureum cv. Mott) di Lahan Terbuka Bekas Penambangan Batu Kapur Kawasan Karst Gombong Jawa Tengah. Biosfera 34 (3): 131137.

Satata, B dan Kusuma, M. E. 2014. Pengaruh Tiga Jenis Pupuk Kotoran Ternak (Sapi, Ayam, dan Kambing) terhadap Pertumbuhan dan Produksi Rumput Brachiaria humidicola. Ilmu Hewani Tropika, Palangka Raya.
Setiawan, A.I. 2002. Memanfaat Kotoran Ternak. PT. Penebar Swadaya, cet-2 Jakarta.

Sirait, J., Tarigan, A. dan Simanikhuru, K. 2013. Karakteristik Morfologi Rumput Gajah Kerdil (Pennisetum purpureum cv Mott) pada Jarak Tanam Berbeda di Dua Agroekosistem di Sumatera Utara. Prosiding Seminar Nasional Teknologi Peternakan dan Veteriner :641 - 649.

Wijaya, K. A. 2008. Nutrisi Tanaman Sebagai Penentu Kualitas Hasil dan Resistensi Alami Tanaman. Prestasi Pustaka, Jakarta.

Wong, C.C. 1991. Shade tolerance of tropical forage. Proceeding of Workshop Forages for Plantation Crops. Ed by Shelton, H. M. and Sturr, W. W. ACIAR No. $32: 64$.

Zahroh F., Muizzudin, dan Chamisijatin. L. 2016. Pengaruh Jenis dan Dosis Pupuk Kandang terhadap Tinggi Tanaman, Luas Daun, dan Berat Basah Rumput Gajah Odot (Pennisetum purpureum $C v$. Mott). Prosiding Seminar Nasional II: $908-914$. 